\title{
KINERJA APARATUR DINAS PERUMAHAN, KAWASAN \\ PERMUKIMAN DAN PERTANAHAN KABUPATEN MAMASA (STUDI: PELAYANAN SERTIFIKASI TANAH PADA BIDANG PERTANAHAN)
}

\author{
Beni Maqi Randan', \\ IProdi Ilmu Pemerintahan, Fakultas Ilmu-Ilmu Sosial dan Ilmu Pemerintahan \\ Universitas Al Asyariah Mandar \\ Email: benidishub@gmail.com
}

\section{$\operatorname{ABSTRACT}$}

This study aims to determine the performance of the Land Sector Apparatus of the Housing and Land Affairs Office of Mamasa Regency. This study uses descriptive qualitative research methods that aim to describe and describe events and phenomena that occur in the field and present data in a systematic, factual, and accurate manner. Data was collected by using observation, interview, and documentation techniques. Researchers used source triangulation to check the validity of research data. Data analysis in this study uses three components consisting of data reduction, data presentation, and drawing conclusions. The results of this study indicate that the performance of the Land Sector Apparatus of the Housing and Land Affairs Office of Mamasa Regency has implemented indicators of form, reliability, guarantee, productivity, responsiveness and accountability. However, not all indicators run well according to community expectations because there are still complaints from the community, the requirements needed and the processes faced by the community are still convoluted and the costs are fairly high.

\section{ABSTRAK}

Penelitian ini bertujian untuk mengetahui kinerja tim di dinas pertanahan kabupaten mamasa dengan realitas yang sangat tepat. Pengumpulan data di tentukan dengan teknik observasi, wawancara, dan dokumentasi. Peneliti menggunakan triagulasi sumber untuk mengecek keabhasan data penelitian. Analisis data dalam penelitian ini menggunakan tiga komponen yaitu reduksi data, visualisasi data, dan penarikan kesimpulan. Hasil penelitian ini menunjukkan bahw a pengoperasian alat pemantau wilayah dinas pemukiman dan wilayah pemerintah kabupaten mamasa telah mmenetapkan indikator penampilan, keandalan, jaminan, produktivitas, daya tanggap, dan tanggung jawab dari masyarakat, persyaratan yang dibutuhkan dan proses yang dihadapi masyarakat masih berbelit-beli serta biaya yang terbilang tinggi.

Kata Kunci: Kinerja Aparatur, Pelayanan Sertifikasi. 


\section{PENDAHULUAN}

Hal terpenting dalam mengukur kinerja sebuah organisasi adalah memberikan penlian karena dapat dijadikan sebagai tolak ukur dalam menetukan keberhasilan dari organisasi tersebut. Adapun untuk pelayanan pemerintah yang memberikan pelayanan kepada masyarakat, menjadi sangat penting untuk mengukur kinerjanya. Sehingga dapat diketahui sejauh mana kinerja organisasi tersebut memberikan pelayanan kepada masyarakat, apakah kinerjanyadalam memberikan pelayanan telah sesuai dengan keinginan masyarakat sebagai pengguna layanan.(Dr. H. Bahrul Kirom, 2015)

Adanya perbaikan kinerja yang lebih terarah sehingga dapat mewujudkan visi dan misi organisasi dan pelayanan publik yang optimal dapat tercapai, sebab tingginya kinerja organisasi akan membuat tugas dan fungsi dari organisasi tersebut lebih efektif dan efesien serta lebih responsive dalam memberikan pelayanan kepada pengguna layanan. (Mahmudi, 2010)

Arif (2015) menyatakan bahwa penilaian kinerja merupakan bentuk penilaian yang berjalan secara otomatis dan sistematik untuk mengetahui hasil kinerja dan seberapa potensi pegawai dalam usaha meningkatkan potensi diri untuk kepentingan organisasi. Sementara Marwansyah (2014: 228) menjelaskan penilaian kinerja adalah cara untuk melihat, menganalisa dan memeriksa serta menilai kinerja baik individu maupun sekelompok pegawai. Adapun Widodo, Eko, Suparno (2015: 130), mengemukakan bahwa penilaian kinerja merupakan pengukuran tingkat kemudian dibandingkan dengan standar kinerja pelayanan yang telah ditetapkan sebagai ukuran dalam menentukan kompensasi, pegembangan, promosi maupun pelatihan-pelatihan bahkan dalam pemberhentian pegawai.

Dalam mewujudkan tujuan organisasi yaitu pencapaian sasaran, visi dan misi sebagai tolak ukur kinerja organisasi maka diperluk an suatu informasi dalam lingkup internal organisasi tersebut. Namun pada kenyataannya, informasi kinerja organisasi pelayanan publik masih sangat terbatas dan belum mudah diakses hal tersebut disebabkan karena pemerintah menganggap kinerja organisasi bukan merupakan sesuatu yang kurang penting.

Tuntutan masyarakat dalam berbagai bidang kebutuhan membuat organisasi-organisasi pelayan publik harus lebih mengoptimalkan lagi kinerjanya, Yang dimana dalam mencapai suatu kinerja dapat terlaksana dengan baik dari organisasi pelayanan publik tersebut sebagaimana yang dipahami prosedur pemerintah yang berbelit -belit, belum efesien dan seringnya terjadi penyalahgunaan kekuasaan dan kewenangan membuat kinerja pemerintah dipertanyakan.(hardiansya, 2011)

Adanya pelayanan yang diberikan oleh aparatur birokrat yaitu sertifikat tanah dan manusia memiliki hak untuk memiliki tanah, maka peran pemerintah sangat penting dalam mengatur kepemilikan tanah. Pemerintah sebagai organisasi yang memiliki otoritas diberi pelimpahan oleh Negara untuk 
menguasai, mengatur, mengurus, menerbitkan serta menyelesaikan segala persoalan penguasaan tanah. (Sinambela, 2011)

Sementara maksud dari memberikan hak -hak tanah kepada masyarakat menurut (A.P. Parlindungan, 2009) adalah pemerintah memberikan kewenangan masyarakat untuk mengelola dan penggunaan tanah dan air menurut aturan-aturan yang berlaku dalam UU No. 5 Tahun 1960, yang menetapkan aturan-aturan pokok di bidang pertanian. yang termasuk kberadaan ruang dalam pasal 16 ayat 1 yang menetapkan hak teritorial sebagai berikut:

1. Hak milik

Hak milik adalah hak terkuat dan terlengkap yang dapat dimiliki seseorang untuk memiliki tanah dengan pemberian harta ini tidak berarti bahwa hak itu mutlak, dan tidak terbatas serta tidak dapat di ganggu gugat. Yang dimaksud dengan turun temurun adalah bahwa hak atas tanah hanya seumur hidup pemegang hak, yang dapat diteruskan oleh ahli waras apabila terjadi suatu peristiwa hukum, yaitu meninggalnya pemegang hak.

2. Hak guna bangunan

Hak pakai suatu ciptaan adalah hak untuk membangun dan memiliki ciptaan di atas tanah yang tidak dimiliki siapa pun, dan dapat diperpanjang sampai dengan 30 tahun dan sampai dengan 20 tahun.

3. Hak guna usaha

Hak guna usaha merupakan hak guna usaha untuk perusahaan pertanian, perikanan atau pembibitan di atas tanah yang dikuasai langsung oleh Negara selama jangka waktu yang ditentukan dalam pasal 5 ayat 29 UU Tahun 1960

4. Hak pakai

Hak pakai adalah hak untuk menggunakan atau memungut hasil dari lahan yang dikuasai langsung oleh Negara atau tanah milik orang lain, yang bukan perjanjian sewa-menyewa atau pengolahan tanah.

5. Hak sewa

Hak sewa merupakan hak terhadap orang perseorangan atau badan hukum untuk mendirikan dan memiliki suatu bangunan di atas tanah milik orang dengan membayar sewa tetapuntuk jangka waktu tertentu yang disepakati oleh penyewa terhadap bangunan.

6. Hak dalam memanfaatkan tanah atau memanen dengan hasil hutan yanag akan dimiliki oleh warga Negara Indonesia dan di atur dengan peraturan pemerintah.

Adanya landasan hukum yang kuat tersebut, bisa menjadi tameng maka apabila terjadi konflik atas tanah, seperti adanya penguasaan terhadap lahan maka pemegang sertifikat asli tanah tersebut bisa menuntut pihak yang melakukan penyerobotan tanah karena berusaha merebut kepemilikan yang sah. Namun meskipun landasan hukum tentang sertifikat tanah begitu kuat akan 
tetapi permasalahan-permasalahan tanah masih banyak dan terus terjadi berulang-ulang.

Terkait permasalahan tanah juga terjadi di Kabupaten Mamasa. Permasalahan tanah yang masih terus terjadi membuat kinerja dari Bidang Pertanahan Mamasa dianggap kurang optimal. Adapun permasalahan tanah di Kabupaten Mamasa diantaranya adalah tentang batas tanah atau batas kepemilikan tanah atau ketidakjelasan batas tanah. Hal tersebut akan menimbulkan konflik pertanahan antara pemilik tanah sah dengan pihak yang sengaja melakukan pengambil alihan hak atas tanah tersebut. Permasalahan lain yang terjadi adalah adanya sertifiakt ganda serta terbitnya sertitikat aspal atau asli tapi palsu.

Hal lain yang membuat kinerja Bidang Pertanahan Kabupaten Mamasa menjadi sorotan adalah mekanisme pendaftaran dengan pemenuhan persyaratan permohonan yang rumit dan menggunakan waktu yang sedikit. Hal tersebut membuat masyarakat pengguna layanan lebih cenderung menggunakan jalur pintas seperti pengurusan menggunakan calo atau notaris yang telah memiliki pengalaman dalam mengurus sertifikat tanah. Biaya yang relatif tinggi serta kemampuan aparatur yang minim dan kurang responnya pegawai pertanahan dalam melakukan pelayanan merupakan deretan keluhan yang menggambarkan pelaksanaan kinerja pelayanan di Bidang Pertanahan Kabupaten Mamasa cukup memprihatinkan. Dari berbagai permasalahan permasalahan pertanahan yang telah diuraikan maka menjadi tanggung jawab bagi Bidang Pertanahan Kabupaten Mamasa untuk menyelesaikan segala permasalahan tersebut.

Dengan adanya sertifikat sebagai bukti hak kepemilikan tanah maka masyarakat akan mendapatkan jaminan kepastian hukum. Namun melihat permasalahan diatas maka pelayanan sertifikasi tanah di Kabupaten Mamasa idak sesuai dengan aturan hukum peraturan pemerintah yang telah diatur dalam PP No. 128 Tahun 2015 akan dikenakan biaya-biaya berikut kepada masyarakat pengguna jaza terkait dengan perencanaan pertahanan/Lahan, seperti proses pendaptaran dan pememnuhan persyaratan yang kompleks atau jenisnya.

Berdasarkan topik di atas terkait dengan proses audit sertifikasi untuk perumahan, pemukiman dan kantor pertanahan kabupaten mamasa, peneliti didorong untuk melakukan survei terhadap kinerja kantor perumahan, fasilitas dan tanah kabupaten mamasa Bidang Pertanahan dalam pelayanan sertifikasi tanah dengan judul penelitian "Kinerja Aparatur Pada Dinas Perumahan Kawasan Permukiman dan Pertanahan Kabupaten Mamasa, Studi : Pelayanan Sertifikasi Tanah Pada Bidang Pertanahan"

\section{METODE PENELITIAN}

Jenis penelitian ini menggunakan metode deskriptif kualitatif, Menuturt Maellong (2010), penelitian kualitatif adalah penelitian yang menempatkan peneliti sebagai wahana utama, yang dapat melaukan kombinasi teknik 
pengumpulan data dan pedoman analisis data. Disisi lain, powerwandari 2015 mengatakan bahwa Mengenai penerbitan sertifikat tanah di kantor real kabupaten Mamasa, dengan adanya data yang diperoleh dari survei akan diinterprestasikan secara kualitatif. Dengan menggunakan metode ini, maka penulis dapat memperoleh kumpulan data-data yang lengkap dan menjelaskanya dengan sangat jelas, sehingga hasil penelitian ini sebenarnya sesuai dengan kondisi dilapangan yang ada. Penelitian ini dilakukan di dinas perumahan kabupaten mamasa mulai dari februari hingga maret 2021.

\section{HASIL DAN PEMBAHASAN}

Berdasarkan hasil wawancara dan observasi yang dilakukan di dinas perumahan kanupaten mamasa, maka dapat di kemukakan pendapat sebagai berikut:

Dalam penelitian ini dimaksud dengan dimensi wujud (tangible) adalah adanya sarana fasilitas kendaraan pribadi dan komunikasi dalam pemberian pelayanan dan dapat merasakan kepuasan yang diberikan oleh pemberi layanan namun begitupun sebaliknya, jika masyarakat sebagai pengguna layanan merasakan pelayanan yang buruk maka secara otomatis masyarakat akan memberikan penilaian yang buruk pula karena masyarakat sebagai pelayanan yang diberikan.

Adapun yang dapat mengetahui kualitas pelayanan publik yang diberikan oleh sektor pertanahan dengan mengukur aspek berwujud (tanggible) sebagai berikut:

Penampilan pegawai dalam memberikan pelayanan publik

Sala satu faktor yang paling besar pengaruny terhadap kualitas pelayanan yang diberikan adalah keterampilan pegawai dalam kaitanya melaksanakan pekerjaan dengan memberikan pelayanan yang jelas terhadap pengguna layanan . Hal ini sesuai dengan pernyataan Plt Kepala Dinas Bapak Gusti Harmiawan. B, ST., M.Si., MH, yang mengatakan bahwa:

"penampilan tentulah berpengaruh dalam memberikan pelayanan, karena yang pertama kali dilihat adalah sikap dan penampilan, makanya saya selalu sarankan agar selalu berpakaian rapi dan berpenampilan menarik bahkan ada aturan yang sudah tetapkan dari pemerintah kabupaten hari ini pakaian ini, hari menggunakan ini, agar terlihat tetap seragam dan memberi kesan enak dipandang mata" (Wawancara. 22 Mei 2021)

Pernyataan diatas tersebut didukung pendapat dari Petugas Loket Ibu Andi Nurta, yang mengatakan bahwa :

"terkait penampilan itu sangat berpengaruh makanya kami selalu ingatkan untuk tetap berpenampilan sopan dalam memberikan pelayanan" (Wawancara. 22 Mei 2021) 
Dari wawancara diatas terlihat penampilan menjadi salah satu yang mendapatkan perhatian karena dianggap dapat memberikan pelayanan kepada pengguna layanan. Sebagaimana yang diungkapkan Kepala Bidang Pertanahan Bapak Kesumajaya, S.Pd, yang mendukung pernyataan sebelumnya yang menyatakan bahwa :

"iya betul, dalam proses memberikan pelayanan kepada masyarakat, pegawai harus selalu terlihat rapih dan sopan ketika memberikan pelayanan (Wawancara. 22 Mei 2021)

Masyarakat tentunya akan merasa senang jika pemberi layanan selain sopan dalam meberikan pelayanan juga berpenampilan menarik.Seperti yang diungkapkan salah satu pemohon Ibu Marlina Limbong, yang menyatakan bahwa :

"pegawai yang memberikan layanan sudah terlihat sangat rapih. Mereka mengenaikan pakaian yang sopan, bagus dilihat" (Wawancara. 23 Mei 2021)

Pendapat diatas dibenarkan oleh pemohon Bapak Muh. Qadri yang peneliti wawancarai yang mengungkapkan bahwa :

"terlihat mereka penampilan sangat bersih dan rapih, mereka juga sopan ketika sedang melayani masyarakat yang datang" (Wawancara. 24 Mei 2021)

Berdasarkan wawancara diatas dapat dikatakan bahwa pegawai pelayan an Bidang Pertanahan Pemukiman sangat memperhatikan penampilan dalam menggunakan pakaian terlihat dari penjelasan beberapa informan yang menangatakan bahwa penampilan pegawai Kantor Bidang Pertanahan sudah sangat baik.

Penampilan layanan harus memaksimalkan penampilan dengan mendukung pemberian layanan yang berkualitas sehingga dapat mencapai tujuan terhadap kepuasan pengguna layanan.

Kenyamanan tempat melakukan pelayanan

Bidang Pertanahan Dinas aset perumahan dan terestrial kabupaten mamasa sebagai penyedia layanan publik yang sangat perluh menyediakan tempat yang sangat nyaman bagi pengguna layanan, kenyaman tempat seperti ruangan luas untuk pelayanan, termasuk ruang tunggu/antrian, tempat duduk, dan hal -hal lain yang mendukung kenyaman buat pengguna layanan agar ketika masyakat yang datang merasakan kenyaman dalam mengurus kebutuhan mereka, apalagi pada waktu-waktu tertentu antrian membludak.

seperti yang diutarakan oleh salah satu pemohon Ibu Marlina, yang mengungkapkan bahwa:

"kondisi Kantor Pertanahan masih sangat perlu dibenahi dan ditingkatkan lagi khususnya kebersihan lingkungan dan tata ruangan yang perlu dirapihkan lagi" (Wawancara. 23 Mei 2021) 
Pernyataan informan dari sakah satu pemohon diatas dibenarkan oleh petugas lapangan Bapak Mukhtar, yang menyatakan bahwa:

“kenyaman memang sangat mempengaruhi kualitas pelayanan. Tempat proses pemberian pelayanan kepada masyarakat disini sempit, terkadang banyak masyarakat dan berdesak-desakan sehingga pelayanan yang kami berikan juga ikutan terganggu, kamijuga tidak bisa menyediakan kursi yang banyak sehingga banyak yang mengeluh" (Wawancara. 22 Mei 2021)

Menanggapi hal tersebut Kepala Bidang Pertanahan Bapak Kesumajaya, S.Pd, menjelaskan bahwa :

"kami terus berbenah, bukan hanya saat pelayanan seperti ini namun juga semua bentuk pekerjaan, adapun terkait dengan pelayanan kepada masyarakat, kenyamanan sekitar tempat pelayanan itu cukup baik namun memang perlu diperbaiki lagi (Wawancara. 23 Mei 2021)

Dari hasil wawancara sebelumnya, kenyamana terhadapa pelayanan yang diberikan oleh dinas pertanahan masih sangat kurang dan terlihat dari banyaknya keluhan dari warga. Hal ini mebuktikan kenyamanan adalah salah satu yang sangat berdampak besar pada kualitas yang tidak menyenangkan seperti lingkungan yang tidak bersih, berdiri karena tidak tersedianya kursi atau tempat duduk, antri diruangan yang sempit dan lain sebagainya maka masyarakat pun akan merasakan ketidak nyamanan. Namun jika masyarakat berada pada tempat dan suasana yang bersih baik dan nyaman maka masyarakat akan tenang dan sabar menunggu antrian.

Kedisiplinan pegawai dalam melaksanakan proses pelayanan

Disiplin merupakan syarat mutlak untuk membentuk sikap, tata krama dan gaya hidup guna dalam membentuk kepribadian pekerja yang bertanggung jawab. Selain itu, dalam proses pemberian pelayanan para agen yang akan memberikan pelayanan harus memiliki kedisiplinan yang baik dalam waktu maupun dalam bekerja secara khusus sesuai dengan kebutuhan masyarakat pengguna layanan.

Berdasarkan hasil wawancara dengan salah satu pemohon, Ibu Antoneta mengatakan bahwa :

'sudah sangat disiplin dalam memberikan pelayanan kepada kami, terlihat dari pelayanan yang mereka lakukan sudah berjalan dengan baik, mereka sudah tepat waktu dan bertanggung jawab" (Wawancara. 23 Mei 2021)

Disiplin adalah merupakan modal utama yang harus dimiliki oleh setiap Pegawai yang terutama dapat diberikan pelayanan yang sangat baik dan maksimal dengan adanya keluhan-keluhan yang di alami dalam melakukan pelayanan sehingga dapat tersedia pelayanan dengan baik dan jelas dari para pengguna layanan.

Dimensi Kehandalan 
Dalam mengukur dimensi dapat ditemukan kepercayaan yang diterapkan oleh sektor teritorial sebagai penyedia layanan dalam upayanya menentukan kualitas layanan publik yang diberikan. Kecermatan pegawai dalam melayani pengguna layanan

Pegawai petugas pelayanan dituntut untuk cermat dalam bekerja atau dalam menyelesaiakan kebutuhan masyarakat, dengan kecermatan maka akan memanilisir kesalahan-kesalahan yang akan terjadi.

Berdasarkan hasil wawancara di atas, maka dapat dikatakan bahwa pegawai dalam melakukan pelayanan sudah sangat cermat seperti yang dikatakan salah satu pemohon Bapak Semuel Tandibamba yang mengungkapkan bahwa :

"selama proses pelayanan saya melihat pegawai pertanahan yang bertugas melayanai kami itu sudah baik dalam melayani, kalaupun ada kesalahanpunitu tidak akan menonjol karena tidak terlihat dan merugikan kami" (Wawancara. 23 Mei 2021)

Pernyataan diatas diperkuat Kepala Seksi Inventarisasi dan Pengadaan Tanah, Bapak Elvis Bangaklele, ST, yang menyatakan bahwa :

"petugas pelayanan sudah cermat dalam melakukan tugasnya, terbukti kami tidak terlalu banyak menerima komplen terkait ketidak puasan dari masyarakat, apa yang mereka urus karena tidak sesuai datanya. Pegawai semaksimal mungkin menggunakan cara agar lebih baik dalam melayani" (Wawancara. 22 Mei 2021)

Dari hasil wawancara di atas, maka dapat dikatakan bahwa pelayanan yang dilakukan oleh pegawai sudah sangat cermat dan jelas dalam melakukan pelayanan terhadap pengguna layanan.

\section{Memiliki Standar Pelayanan yang jelas}

Standar pelayanan akan mempermudah alur proses pelayanan. Bidang Pertanahan telah memiliki Standar Operasional Prosedur, SOP inilah yang digunakan dalam memberikan pelayanan kepada masyarakat. SOP ini mencakup prosedur layanan, jam layanan, peralatan dan insfraktruktur, produk pelayanan, dan kemampuan agen layanan. Seperti yang diungkapkan Plt Kepala Dinas Bapak Gusti Harmiawan B, ST., M.Si., MH, yang menyatakan bahwa :

"kami memiliki Standar Operasioal Prosedur, inilah yang menjadi pedoman pegawai kami dalam melayani masyarakat" (Wawancara 22 Mei 2021)

Pernyataan tersebut dibenarkan Kepala Bidang Pertanahan Bapak Kesumajaya, S.Pd, yang menjelaskan bahwa :

"iya ada SOP, SOP inilah yang mengarahkan petugas kami melaksakan tugas-tugasnya seperti bagaimana alur pelayanan, berapa biayanya dan lain-lain" (Wawancara 22 April 2021)

Dapat memiliki pelayanan standar yang sangat jelas dan berguna untuk dapat melaksanakan tugasnya, khususnya petugas pelayanan untuk memenuhi kebutuhan pengguna jaza dengan mengacu pada standar pelayanan yang diberikan. 
Dimensi Jaminan

Dimensi Jaminan (Assurance) adalah pengetahuan, keterampilan, kesopanan, kepercayaan kariawan, tidak ada bahaya, tidak ada risiko, dan tidak adanya pertanyaan. Jaminan adalah upaya untuk melindungi komunitas atau warganya dari risiko terjadi dan akan mengganggu struktur kehidupan normal . Sedangkan untuk mengukur tingkat assurance atau kepastian untuk mengetahui tingkat kualitas pelayanan publik yang diberikan oleh kementrian perumahan dan pertanahan kabupaten mamasa dapat digunakan indikator sebagai berikut:

Petugas akan memberikan jaminan dengan tepat waktu dan tepat sasaran

Untuk mengukur kualitas pelayanan yang diberikan salah satunya adalah jaminan tepat waktu. Jaminan tepat waktu pada Bidang Pertanahan diberikan pegawai yaitu mengusahakan penyelesaikan keperluan masyarakat dengan tepat waktu. Jika suang hari atau saat memakai tidak akan dapat diselesaikan berharihari diambi di loket pelayanan dengan memperlihatkan tanda bukti pengambilan yang diberikan. Seperti yang jelaskan Kepala Bidang Pertanahan, Bapak Kesumajaya, S.Pd, yang mengatakan bahwa :

"tentu saja ada, kami kan ada SOP. Disitu diatur tentang proses pelayanan, waktu pelayanan dan seterusnya. Jadi jaminan penyelesaian tetap kami berikan kepada masyarakat. Apabila yang diurus masyarakat bisa diselesaikan satu hari maka akan diselesaikan saat itu juga tapi jika pengurusan tersebut membutuhkan beberapa hari maka kami akan meminta masyarakat kembali tapi tetap ada waktunya yang kami berikan kepada masyarakat tentang penyelesaian apa yang mereka urus tersebut" (22 Mei 2021)

Layanan utilitas harunya menyediakan layanan kepada pengguna saera tepat waktu sehingga mereka dapat yakin bahwa kebutuhan mereka terpenuhi. Petuga dapat memberikan jaminan dan biaya dalam melakukan pelayanan

Biaya pemenuhan kebutuhan sektor pertanahan dinas pertanahan perumahan mamasa telah diidentifikasi dan dijelaskan secara kolektif. Rincian anggaranpun telah tertera pada point-point persyaratan yang diterima oleh masyarakat, hal ini diungkapkan pet ugas loket Ibu Andi Nurta, yang menyatakan bahwa :

"mengenai biaya itu tertera jelas di formulir atau lembar persyaratan, jadi rinciannya ada semua di lembaran itu. Masyarakat langsung tahu apa saja yang mereka biayai (Wawancara 22 April 2021)

Jaminan biaya bagi petugas pelayanan, masyarakat pengguna jaza dapat dengan cepat mengetahui berapa anggaran yang harus dikeluarkan.

Produktifitas

Produktivitas merupakan perbandingan jumlah usaha yang dilakukan dan hasil yang diperoleh selama dalam periode waktu tert entu, dengan hubungan antara input dan output. Adapun dalam penelitian ini indikator produktifitas 
berbicara tentang sejauh mana pelayanan dalam peralihan ha katas tanah yang tingkat kepuasan yang dirasakan oleh penerima layanan.

Pelayanan sertifikasi tanah yang diberikan oleh Bidang Pertahanan Dinas diarahkan sesuai Visi organisasi yaitu memberikan pelayanan yang maksimal untuk mewujudkan tanah dan pertanahan dengan penuh keadilan, berkelanjutan, dan kemakmuran rakyat serta memberikan layanan kepada masyarakat. Sebagaimana yang diungkapkan oleh Kepala Bidang Pertanahan, Kusumakaya, S.Pd, yang menyatakan bahwa :

"pelayanan yang kami berikan sesuai dengan visi dinas pertanahan, yang jelas jika syarat-syarat telah dipenuhi oleh pemohon maka kita segara memberikan pelayanan. Masalah-masalah yang diadukan oleh masyarakat kepada kami langsung ditangani sesuai dengan aturanaturan yang berlaku. Tapi yang jadi masalah adalah kadang berkasberkas pemohon yang kami minta tidak lengkap, nah itu yang membuat kadang prosesnya menjadi semakin lama dan akhirnya tidak sesuai dengan waktu yang ada diatur di SOP' (Wawancara, 22 Mei 2021)

Dari penjelasan informan tersebut dapat dikatakan bahwa Bidang Pertanahan sudah sesuai target pelayanan yang mengacu pada Standar terlambat diterbitkan karena masyarakat tidak memperhatikan dan kurang memahami syarat-syarat yang harus dipenuhi sebagai kebutuhan untuk mengeluarkan sertifikat, hal inilah menjadi penghambat proses penertiban sertifikat baru. Terkait masalah tersebut, ketika di konfirmasi pihak Bidang Pertanahan Mamasa mengungkapkan tentang berbagai upaya yang mereka telah lakukan sebagaimana yang dikatakan oleh Kepala Bidang Pertanahan Kusumajaya, S.Pd, yang mengatakan bahwa :

"banyak memang masyarakat yang belum terlalu paham tentang pemenuhan syarat-syarat yang dibutuhkan seperti jika mereka bermohon untuk balik nama, itulah yang membuat kami melakukan berbagai upaya seperti sosialisasi, terus melakukan penyuluhan pada masyarakat, kami berkordinasi dengan pihak Pemda dan Kecamatan, membagikan brosurbrosur yang kami titip juga dibeberapa kantor kecamatan, disitu tertera harga dan syarat-syarat pengurusannya jika bermohon, masyarakat juga bisa langsung bertanya ke oket informasi. Ini kami lakukan dengan harapan masyarakat semakin tahu dan paham bagaimana jika mereka bermohon ke Pertanahan. Dan ini terbukti cukup efektif meski tetap saja masih ada masyarakat yang memasukan kurang lengkap tapi sudah sangat sedikit, beda dengan yang dulu" (Wawancara, 22 Mei 2021)

Pernyataan ini didukung oleh penjelasan Petugas Loket penerimaan berkas, Sisca Novianthy, yang menyatakan bahwa :

"iya, dulu itu hampir semua yang datang kesini akan kembali-kembali memperbaiki berkasnya namun sekarang sudah sangat kurang, itu karna beberapa pemohon sudah banyak yang membaca seperti brosur yang kami 
sebar termasuk mendapatkan informasi dari keluarga atau teman mereka yang sudah perna mengurus disini, kamijuga aktif memberikan penjelasan jika ada yang baru mengurus dan tidak mendapatkan informasi diluar sehingga ketika mereka datang kebutuhan syarat-syaratnya sudah kita siapkan" (Wawancara 22 Mei 2021)

Pendapat tersebut juga dikuatkan oleh penjelasan salah satu pemohon Bapak Muh. Qadri, yang mengatakan bahwa :

"waktu saya mengurus sertifikat tanah, saya ditanya oleh petugas layanan apakah berkas saya sudah dilengkapi sesuai yang dipersyaratkan, kemudian saya sodorkan berkas yang saya bawah dan diperiksa oleh petugas layanan tersebut. Setelah diperiksa ternyata masih ada berkas yang belum saya lengkapi, kemudian petugas tersebut mengambil salah satu berk as sebagai contoh dan pedoman dalam melengkapi berkas-berkas saya" (Wawancara, 24 Mei 2021)

Dari wawancara diatas dapat dilihat bahwa Bidang Pertanahan Dinas telah melakukan beberapa upaya untuk menangani masalah masalah yang banyak dihadapi oleh masyarakat pemohon seperti kurangnya pengetahuan pemohon atas syarat-syarat yang harus dipenuhi jika mengajukan permohonan peralihan hak atas tanah. Dan upaya tersebut bisa dikatakan cukup efektif dan terealisasi dengan baik, hal ini terlihat dari tanggapan para informan pengguna jasa pelayanan Bidang Pertanahan ketika mereka datang bertanya ke petugas loket pelayanan sampai akhirnya mereka menunggu terbitnya sertifikat baru peralihan hak atas tanah mereka. Target tepat waktu terhitung semenjak menyerahkan berkas persyaratan kepada petugas loket sampai terbitnya sertifikat baru dan mutu pelayanan telah sesuai.

Informasi diatas maka dapat disimpulkan bahwa produktifitas Bidang Pertanahan Pemukiman dan Pertanahan Kabupaten Mamasa sudah semakin dapat dilaksanakan dengan sebagaimana wawancara wawancara beberapa informan yang memberikan tanggapan yang baik terhadap pelayanan dari Pihak Pertanahan Kabupaten Mamasa yang telah memperbaiki proses pelayanan seperti memberikan penjelasan kepada pemohon yang belum mengetahui dokumen apa yang harus disiapkan ketika mengajukan permohonan peralihan ha katas tanah dan bagaimana prosedurnya. Penyebaran brosur di kantor-kantor pemerintah juga efektif. dilihat mencapai target tepat waktu dan t erselesaikan termasuk mutu pelayanan yang diberikan juga sesuai harapan.

Responsivitas

Responsivitas merupakan kemampuan sebuah organisasi mengetahui apa yang dibutuhkan oleh masyarakat, mampu menyusun rencana pelayanan dengan mengembangkan program dan mengutamakan penyampaian pelayanan sesuai kebutuhan dan aspirasi masyarakat. Dimana, responsivitas mengarah kepada keselarasan kegiatan pelayanan dengan aspirasi masyarakat terhadap program pelayanan publik. 
Secara langsung, Responsivitas menggambarkan kemampuan Kantor Bidang Pertanahan dalam memberikan kinerja pelayanan untuk mengatasi, memenuhi kebutuhan, menanggapi keluhan atau tuntutan serta masukan masyarakat ketika menangani masalah sertifikasi tanah terkhusus permohonan sertifikat peralihan ha katas tanah.

Bidang Pertahanan juga harus mampu menangani permasalahan baik berupa keluhan, tuntutan, pemenuhan kebutuhan menerima kontribusi masyarakat dengan menyelesaikan masalah pengalihan atas hak tana, dan mengikuti proses yang direncanakan untuk memastikan bahwa tidak ada hambatan bagi masyarakat saat meminta alikan hak tanah.

pelayanan sertifikat peralihan hak atas tanah juga telah menerima keluhan, tuntutan terkait persoalan peralihan ha katas tanah termasuk menampung masukan masyarakat. Memberikan penyuluhan kepada masyarakat melalui kerjasama dengan BPN dan Pemerintah Daerah serta upaya pembuatan brosur, sebagaimana yang dikemukakan oleh Plt. Kepala Dinas Gusti Harmiawan B, ST., M.Si., MH, mengatakan bahwa :

"bersama pihak BPN dan PEMDA kami melakukan penyuluhan dan sosialisasi perundang-undangan, memberikan informasi tentang hukumhukum pertanahan serta pelayanan sertifikasi tanah, membagikan brosur. kegiatan ini diharapkan dengan harapan masyarakat ini memahami dan mengetahui syarat dan biaya yang mereka keluarkan ketika melakukan permohonan sertifikasi tanah" (Wawancara 22 Mei 2021)

Responsivitas Bidang Pertanahan begitu sangat penting dalam merespon keluhan keluhan masyarakat, kebutuhan masyarakat dan masukan masyarakat, karena hal tersebut menunjukkan bahwa respon telah merespon segala permasalahan yang dirasakan oleh warga yang sangat kompleks. Dengan responsivitas yang tinggi maka kinerja yang baik akan mudah diwujudkan.

Akuntabilitas

Mengenai pemberian jasa dalam pelayanan penerbitan hak milik, khususnya di bidang pertanahan, merupakan cara pengalihan hak pakai atas tanah kepada pihak-pihak yang berhak dan berwenang untuk menuntut tanggung jawab. Tanggung jawab bidang pertanahan badan pertanahan dan perumahan kabupaten mamasa adalah badan pertanahan nasional repoblik Indonesia (BPN RI).

Perwujudan tanggungjawab terhadap departemen tanah perumahan dan habitat kantor dalam atribusi dan pelaksanaan fungsinya. Mamasa berjalan sangat baik bahkan perumusan sangat rutin dilaksanakan maupun yang sifatnya insedentil sebagaimana yang diungkapkan oleh Plt, Kepala Dinas Gusti Harmiawan. B, ST., M.Si., MH, yang menjelaskan bahwa :

"sudah ada formulasi pertanggungjawaban dalam bentuk laporan kegiatan baik kegiatan yang rutin dilaksanakan maupun yang sifatnya tiba-tiba, 
seperti jika ada program yang dibiayai oleh pemerintah" (Wawancara 22 Mei 2021)

Sebelumnya informasih menjelaskan bahwa menjadi tanggung jawab devartemen pertanahan sebagai pemilik untuk mendapatkan sertifikat tanah, kemudian departemen pertanahan dari properti dikabupaten mamasa harus memiliki sertifikat kepemilikan.

Pelaksanaan urusan kewilayahan oleh dinas perumahan dan pertanahan kabupaten mamasa tugasnya sebagai satu satunya pemberi layanan sertifikat tanah mempunyai beberapa acuan atau pedoman yang digunakan, sebagaimana yang disampaikan Kepala Bidang Pertanahan Kusumajaya, ST. yang menjelaskan bahwa :

"dalam melaksanakan tugas dan fungsi Pertanahan Kabupate Mamasa, memiliki acuan atau pedoman selain ketemtuan pertanahan pada umunya yaitu SOP atau Standar Operasional Prosedur Pengaturan, ada peraturan pemerintah terkait tarif jenis penerimaan Negara bukan pakjak, dan undang-undang pertanahan lainnya" (Wawancara 22 Mei 2021)

Pernyataan tersebut diatas didukung oleh penjelasan Kepala Seksi Inventarisasi dan Pengadaan tanah Elvis Bangaklele, ST, yang mengatakan bahwa:

"jelas kami memiliki pedoman dalam menjalankan tugas pelayanan kami, dan banyak yang kami gunakan. Ini untuk mewujudkan atau memberikan pelayanan yang maksimal kepada masyarakat, seperti biaya yang mereka harus keluarkan itu sudah aturannya. Kegiatan yang kami lakukan kami buat laporan pertanggungjawaban. Jadi semua bagian yang ada disini itu membuat laporan masing-masing sesuai dengan apa yang mereka lakukan, nantinya laporan itu dikumpulkan jadi satu" (Wawancara 22 Mei 2021)

Pernyataan tersebut didukung oleh Petugas Loket penerimaan berkas Andi Nurta, yang menyatakan bahwa :

"tanggungjawab saya adalah memperifikasi berkas-berkas, kami teliti berkas yang masuk apa sudah sesuai atau tidak, apakah sudah lengkap atau belum karena jika diloloskan pasti akan menimbulkan maslah nantinya, kalau tidak lengkap langsung kamikembalikan dan meminta untuk melengkapinya" (Wawancara 23 Mei 2021)

Komentar dari orang dalam sebelumnya menunjukkan bahwa industri pertanahan sedang berusaha menyelesaikan tugasnya dengan benar. Artinya, kami meninjau semua dokumen yang masuk dan jika di anggap tidak lengkap, akan diberikan konpensasi kembali untuk mwenyelesaikan pendaptaran yang tidak lengkap.

Dalam pemeriksaan dokumen permohonan balik nama yang paling penting dioeriksa adalah apakah sertifikat yang akan dibaik anama tersebut adalah sertifikat asli atau palsu karena di daerah Mamasa sendiri banyak sertifikat asli tapi palsu termasuk banyak beredar sertifikat ganda sehingga perlu kehati-hatian 
untuk meneliti kedua sertifikat tersebut yang mana yang asli dan yang palsu. Karena tanggungjawab tersebut maka untuk mencari kebenarannya melalui data yang ada di Kantor Bidang Pertanahan Kabupaten Mamasa. Seperti yang diungkapkan Kepala Bidang Pertanahan Kusumajaya ST, yang menjelaskan bahwa :

"jika ditemukan sertifikat asli tapi palsu ataupun sertifikat ganda, kita langsung investigasi untuk mencari kebenarannya, misalnya untuk sertifikat palsu kita cek nomor seri sertifikat dan pengamannya termasuk capnya kita juga periksa dan pejabat yang menanda tangani sertifikat tersebut kita teliti apakah sesuai atau tidak. Seperti itu jika ingin mengecek sertifikat ganda"( Wawancara 22 Mei 2021)

Dari berbagai hasil wawancara diatas maka dapat dikatakan bahwa akuntabilitas di bidang pertanahan belum terlalu maksimal. Hal ini bisa dilihat laporan pertanggungjawaban yang sifatnya insedentil, dari beberapa pendapat yang dikemukakan oleh masyarakat pengguna layanan juga yang masih merasakan kesulitan dalam peralihan hak atas nama dalam balik nama pada sertifikat mereka. Beberapa informan menganggap prosesnya terlalu rumit untuk membalik nama tersebut. Akan tetapi hal positif yang dilakukan sebagai tanggung jawab dari Bagian Pertanahan kedua belah pihak yang bersengketa.

\section{KESIMPULAN}

Berdasarkan hasil penelitian dan pembahasan sebelumnya dapat di simpulkan bahwa kinerja sektor pertanahan di kabupaten mamasa adalah sebagai berikut:

Bahwa dari indikator penelitian yang digunakan pada penelitian ini dapat disimpulkan bahwa penampilan, kenyamanan, kedisiplinan, kecermatan, standar pelayanan yang jelas dan ketepatan waktu serta jaminan kepastian biaya sudah diterapkan Bidang Pertanahan.

Dalam memberikan pelayanan peralihan hak atas tanah dapat disimpulkan bahwa sudah sesuai (SOP) yang diterapkan.

\section{SARAN DAN REKOMENDASI}

Berdasarkan temuan di atas, beberapa dokumentasi penulis seperti proposisi di harapkan dapat membantu meningkatkan efisien operasional kantor perumahan dan perumahan sektor pertanahan kabupaten Mamasa dalam pemberian pelayanan dan membuat saran.

Penyederhanaan prosedur dalam peralihan hak atas tanah terutama balik nama perlu mendapatkan perhatian serius dari Bidang Pertanahan Mamasa sebaiknya memangkas waktu penyelesaian pengurusan sertifikat tanah menjadi lebih pendek, waktu yang digunakan untuk penerbitan satu sertifikat 
membutuhkan waktu penyelesaian sampai 98 hari terbilang sangat lama. dan Pertanahan Bidang Pertanahan Kabupaten Mamasa hendaknya melakukan rapat evaluasi kinerja yang intensif dengan tujuan mengevaluasi kinerja sehingga dapat memperbaiki kekurangan-kekurangan untuk menjadi lebih baik.

\section{DAFTAR PUSTAKA}

A.P. Parlindungan, 2009. Pendaftaran Tanah di Indonesia, Bandung: Mandar Maju

Arif N.R.A \& Yusuf B (eds). (2015) manajemen sumber daya manusia di lembaga keuangan syariah Jakarta. Raja Grafindo Persada

Dr.H.Bahrul kirom, 2015. Mengukur kinerja pelayanan dan kepuasan konsumen, Pustaka Reka cipta, Bandung.

Hardiansyah, 2011. Kualitas Pelayanan Publik : Konsep, Dimensi, Indikator dan Implementasinya. Yogyakarta : Gava Media.

Mahmudi. 2010. Manajemen Kinerja Sektor Publik, Edisi. kedua. Sekolah Tinggi Ilmu Manajemen YKPN. Yogyakarta

Marwansyah. 2014. Manajemen Sumber Daya Manusia, Edisi Kedua, Alfabeta, Bandung.

Moleong Lexy, 2010, Metode Penelitian Kualitatif, CV. Remaja, Bandung

Poerwandari, E. K. (2005). Pendekatan kualitatif untuk penelitian perilaku manusia (edisi.Ketiga). Depok: LPSP3 Fakultas Psikologi Universitas Indonesia.

Sinambela, Dr. Lijan Poltak. 2011. Reformasi Pelayanan Publik (Teori, kebijakan dan implementasi). Jakarta: Bumi Aksara

Widodo, Eko, Suparno. 2015. Manajemen Pengembangan Sumber Daya Manusia. Yogyakarta: Pustaka Pelajar.

Undang-undang No 25 Tahun 2009 tentang Pelayanan publik.

PP No. 128 Tahun 2015 tentang Jenis dan Tarif atas Jenis Penerimaan Negara Bukan Pajak

Peraturan Pemerintah Republik Indonesia Nomor 24 tahun 1997 pasal 5 tentang pendaftaran tanah. 